\title{
EFFECTIVENESS OF CITRUS FRUIT IN RELIEVING NAUSEA DURING PREGNANCY IN TANJUNGPINANG, KEPULAUAN RIAU, INDONESIA
}

\author{
Astri Yulia Sari Lubis, Ashar Abilowo, \\ Vina Jayanti,Nurul Aini Suria Saputri \\ Midwifery Program, School of Health Polytechnics, Ministry of Health \\ Tanjungpinang
}

\begin{abstract}
Background: Nausea and vomiting are among the common problems in the first half of pregnancy. Approximately 80\% percent of women are affected during pregnancy, along with significant impact on their quality of life. The reason behind gestational nausea and vomiting is not well-understood. Treatment of gestational nausea and vomiting is rarely so successful that the pregnant women could reach to a full recovery. This study aimed to determine effectiveness of citrus fruit in relieving nausea during pregnancy in Tanjungpinang, Riau.

Subjects and Method: This was quasi-experiment after only with control design carried out at Puskesmas (Community Health Center) Sei Jang, Tanjungpinang, Riau. A sample of 35 pregnant women was selected for this study, consisting of 17 women in the intervention (citrus fruit) group and 18 women in the control group. The dependent variable was nausea. The independent variable was citrus fruit. The data were collected by questionnaire and analyzed by a chisquare test with Odd Ratio (OR) as the measured of effect.

Results: Percent of women who had nausea in the intervention group was lower than counterpart in the control group ( $\mathrm{OR}=0.45 ; \mathrm{p}=0.028)$.

Conclusion: Citrus fruit is effective to relieve nausea among pregnant women.
\end{abstract}

Keywords: citrus fruit, nausea.

\section{Correspondence:}

Astri Yulia Sari Lubis. Midwifery Program, School of Health Polytechnics, Ministry of Tanjungpinang, Riau. Email: sarilubis_cantik@yahoo.co.id.

Mobile: 085743401971. 